\title{
IMPROVING STUDENTS' WRITING ABILITY BY USING LIST, INQUIRE, NOTE CASE STUDY AT AKADEMI ANALIS KESEHATAN MUHAMADIYAH MAKASSAR
}

\author{
Fitri Arniati ${ }^{1)}$ \\ ${ }^{1)}$ Akademi Analis Kesehatan Muhammadiyah Makassar \\ Alamat Korespondensi: fitriarniatil68@gmail.com
}

\begin{abstract}
This research aimed at findings out whether or not the students were able to improve their writing strategy and whether the students able to use List, Inquire and Note Strategy in writing or not. This research used a pre - experimental method with one group pre - test and post-test design. The population was the second grade students of Analkes Muhammdiyah Makassar. The sample were 24 students by using purposive sampling by taking one class. The data was analyzed into precentage, mean score analysis and value of $t$-test. The result of the data analysis showed that the students' writing achievement, in pre - test was $X_{1}=54,6$ and post - test $X_{2}=71,1$. The result of the $t$-test value was $(24,19)$ is greater than the $t$-table value was $(2,601)$ this indicates that the null hypothesis $\left(H_{0}\right)$ is rejected and the alternative hypothesis $\left(H_{1}\right)$ is accepted. There is significant difference of the students' writing achievement before and after presenting materials by using LINK strategy. Based on the findings and discussions of the research the writer concludes that using List, Inquire, Note, Strategy can improve the ability of the students of Analkes Muhammadiyah in writing.
\end{abstract}

Keywords : Improve, Strategy, Writing

\section{BACKGROUND}

There are four skills in learning English as the second language. They are listening, speaking, reading and writing. All of the skills are important and each supposes the other to improve one's mastery of language. The writer does not discuss all language skill but the limits to discuss especially in writing. The students were difficult to express their idea and their thought when they were required to write text. And the teacher had problem related to the teaching and learning of writing.

Basically, writing means produce message written language (Bram in Masdjamiah (2000). It involves an active process to organize and formulated the ideas on the paper so that the reader can follow the writer's messages as well as in oral form. But we should know that writing requires in accurate and practical grammar, word choice and spelling, punctuation and vocabulary. Writing is thinking on paper. Thinking is mood at work finding facts, seeing relationship, testing the truth of term, reaching conclusion, forming, and opinion. In this way, our mind produces language a huge variety of ideas and the facts that support than are the materials, which go into any piece writing (Meyer, 1992). Writing means to produce a message into written language. It involves an active process to organize and formulate the ideas on the paper so that the reader can follow the writer's messages. Writing is one of the four language skills that play important role in human communication. It is used to communicate with other people states that writing has been involved in societies as a result of cultural change creating communication needs which cannot be met by spoken language.

Writing is a productive skills (Harmer in Masdjamiah, 2000) which involves though and emotion. It is a media of communication through writing message can be existed for a long time. Byrne (1984: 1) states that writing wasclearly 
much more than the production of symbol as speech is more than the production of sounds. The symbols have been arranged according to form certain conventions, to form word and word have to be arranged to form sentences. However, we do not write just one sentences or a number of sentences arranged in particular order and linked together in certain ways. Writing involves the according of message of some kind; that is to translate throughout into language.

Writing a composition means we compose meaning of something that we want to tell through written material. Writing is a major tool for learning Largan in Masdjamiah (2000) says that writing is a skill that anyone can learn with practice. When we write, we give full shape to our thought and then put into written form.

Based on the on statements by some sources above we can conclude that writing is productive skills involves though and mind as the graphic recitation of language that is composed of many languages.

Vaughan \& Estes (1986) describes those teaching tips of List, Inqure, and know strategy are as follows:

a) List

Select a word or idea that is central to the upcoming lesson, write it on the board, and ask students to brainstorm and list associated words or ideas from their background knowledge. Allow three minutes for them to complete this step. Next, have students identify one of the ideas from their list and note them on the board. If time permits, have students provide an additional word.

b) Inquire

The teacher requires the students find out as much as they can about the list items by interviewing each other and encourage the students to inquire about the item on the list. During this stage students may ask other students for classification, elaboration or examples. At this step, resist the temptation to explain list items yourself. c) Note

Give students one minute to list everything they now can think of that is related to the central idea. Then, the teacher requires the students to make paragraph base on the topic by developing their idea that they can get from the list item.

\section{RESEARCH DESIGN \\ Instrument of the Research}

The instrument was used to collecting data was written test, for pretest and post-test. The pre-test was used to measure the basic ability of students in writing. The post-test was used to measure the ability of the students after giving the treatment based on the List, Inquire, Note.

\section{Procedure of Collecting Data}

The procedure in collecting data in this research were :

\section{Pre Test}

As a pre-test, the students were given a writing test to know the ability of the students in writing.

\section{Treatment}

After giving pre-test, the researcher gave treatment for the students in three meetings.

\section{Post-Test}

After giving the treatment, researcher gave post-test to the students. The test was same as researcher gave in pre-test. The post-test was given to find out the result after giving treatment.

\section{FINDING AND DISCUSSION}

Writing test in descriptive test was given before treatment. It was conducted in order to investigate the initial achievement in writing ability of students. This pre-test was given one time meeting before the researcher set up the post-test. The result of the test then used as the initial reflection of study; therefore the researcher could give treatment that considerably effective in solving the problems faced in writing ability.

The result of this research deals with the description of students writing ability based on the five elements of 
writing, they are content, organization, vocabulary, language use, mechanics and rate percentage of students, pre-test and post-test scores, the mean scores, t-test value, and the hypothesis testing.

The researcher collected the data by using pre-test and post-test. a pre-test was given before the students having treatments. It aimed at finding out the students' prior writing ability. After the students having treatment, they were given a post-test. It aimed at finding out the students' writing achievement.

The results of pre-test and post-test were compared to know whether or not there was a significance achievement of the students' writing ability. In pre-test the researcher provided the students one free writing in descriptive test. The students were asked to write a descriptive test by List, Inquire, Note in 90 minutes.

During the pre-test was given, the situation in the class. Most students found many difficulties in writing descriptive test. Students still used dictionary in looking for a right word, and students also had problem in punctuation. After having treatment, the students' difficulties could be minimized. It was known after the researcher had conducted the post-test. The followings are the tables of the students result both in pre-test and posttest.

Table 1. The total row score of students' pre-test (X1) and post test (X2), gain or difference with the matched pairs $(D)$, and the square of the gain $\left(D^{2}\right)$

\begin{tabular}{|c|c|c|c|c|}
\hline Name of the Students & $\begin{array}{l}\text { Pre-test } \\
\text { (X1) }\end{array}$ & $\begin{array}{l}\text { Post-test } \\
\text { (X2) }\end{array}$ & $\begin{array}{l}\text { Gain (D) } \\
\text { (X2-X1) }\end{array}$ & $\mathrm{D}^{2}$ \\
\hline Y.A.A.L & 51 & 68 & 17 & 289 \\
\hline K.S.K & 55 & 72 & 17 & 289 \\
\hline M.R.B & 54 & 70 & 16 & 256 \\
\hline M.R.L & 48 & 68 & 20 & 400 \\
\hline A.O.A.M & 47 & 69 & 22 & 484 \\
\hline J.A & 60 & 73 & 13 & 169 \\
\hline G.K.S & 52 & 70 & 18 & 324 \\
\hline I.R.D.A & 59 & 73 & 14 & 196 \\
\hline F.X.L.K & 48 & 60 & 12 & 144 \\
\hline A.P.F.A & 51 & 72 & 21 & 441 \\
\hline M.B.B & 54 & 70 & 16 & 256 \\
\hline E.L.R & 54 & 70 & 16 & 256 \\
\hline B.T.S & 60 & 72 & 12 & 144 \\
\hline Y.D.B.H & 42 & 61 & 19 & 361 \\
\hline M.R.H & 59 & 71 & 12 & 144 \\
\hline P.D.B & 68 & 87 & 19 & 361 \\
\hline Y.S.D & 54 & 72 & 18 & 324 \\
\hline I.R.D & 52 & 70 & 18 & 324 \\
\hline S.H & 55 & 68 & 13 & 169 \\
\hline A.L.R & 55 & 64 & 9 & 81 \\
\hline T.I.P & 62 & 78 & 16 & 256 \\
\hline L.L.H & 52 & 72 & 20 & 400 \\
\hline S.A.K & 66 & 86 & 20 & 400 \\
\hline R.D.T & 54 & 71 & 17 & 289 \\
\hline $\mathrm{N}=24$ & $\overline{\sum X 1}=1312$ & $\sum X 2=1707$ & $\sum \mathrm{D}=\mathbf{3 9 5}$ & )$^{2}=675$ \\
\hline
\end{tabular}


Based on the table 1. above, the total score of pre-test $\left(\sum X 1\right)$ was 1312 and the total raw of post-test $\left(\sum X 2\right)$ was 1707. The gain or the difference between the match pair $\left(\sum D\right)$ was 395 and the square of $\operatorname{gain}\left(D^{2}\right)$ was 6757. The minimum gain (D) of students' score was 0 and the maximum score of gain (D) was 100.

\section{CONCLUSION}

Based on the results of data analysis and findings in the previous, it can be concluded that:

1. The results between the pre-test and the post-test of students who were taught writing List, Inquire, Note through descriptive text was significant, where the mean score of students' writing in pre-test were 54,6 classified as poor to fair score and the mean score of students' writing in post-test were 71,1 classified as average to good score.

2. The use of List, Inquire, Note, Know Strategy can improve the students' writing ability of the eleventh grade students of Analkes Muhammadiyah before being taught List, Inquire, Note through descriptive text method, the students' achievement in writing was classified as poor to fair $\left(\overline{X_{1}}=54,6\right)$ It could be seen from the table in appendix that there was none student $(0 \%)$ got very good to excellent score, there was 1 student $(4,2 \%)$ got average to good score, there were 21 students $(87,5 \%)$ got poor to fair score, and there were 2 students $(8,3 \%)$ got very poor score.

3. The student's achievement in writing was classified as average to good score were $\left(\overline{X_{2}}=71,1\right)$. There were 2 students $(8,3 \%)$ got very good to excellent score, there were 19 students $(79,2 \%)$ got average to good score, there were 3 students $(12,5 \%)$ got poor to fair score, there was none students $(0 \%)$ got very poor score. It means that List, Inquire, Note through descriptive text was effective in improving the students' writing ability.
4. Based on the result of data above the researcher concluded that, "using List, Inquire, Note effectively improve students' writing ability"

\section{BIBLIOGRAPHY}

Anita. 2009. Improving the students' writing ability to write through clustering technique (Thesis). Makassar: Universitas Muhammadiyah Makassar.

Byrne, D. 1984. Teaching Writing Skill. London; Longman Group Ltd. Retrieved on May $2^{\text {nd }} 2013$.

Copeland, M. 1998. Kansas: KSDE Writing Consultant. Kansas State Department of Education.

Gay, L. R. 1987. Education Research. London: Charles E. Mevil Publishing. A Bel \& Howell Company.

Hadiah, Y. 2008. Improving English Speaking Skills of The Second Year Students of SMP Negeri 3 Makassar Through Charades.

Jacobs, G.M, and Small, J. 2003. Combining dictogloss and Cooperative Learning to Promote Language Learning. Available from: www.worldoffiles.net

Kroma, S. 1988. Action research in teaching composition. London : Longman.

Margareta, M.1997. Student Ability to Write Application Letter of Language (Thesis). Makassar: Universitas Negeri Makassar.

Masdjamiah, D. J. 2000. Using Strips picture to guided Students to Write English Paragraphs (Thesis). Makassar: Universitas Negeri Makassar.

Meyer, A. 1992. Writing with Confidence. New York: Harper Collins Publisher.

Neny, N. 2004. The correlation Between Ability and Interest Students in Writing the English Journals (Thesis). Makassar: Universitas Muhammadiyah Makassar.

Vaughn, J., and Estes, J. 1986. Reading and reasoning beyond the primary grade. Boston, MA: Allyn and Bacon. 
Whison, George and Burks. 1980.

Education

Publishing,

Line

Let's Write English. New York: Litton 
